\title{
A Study on Bioaccumulation of Heavy Metals in two Anuran Tadpoles: Clinotarsus alticola and Leptobrachium smithi from Rosekandy Tea Estate, Cachar, Assam
}

\author{
PAMMI SINGH ${ }^{1}$, MITHRA DEY $^{1 *}$ and SUNKAM NARAYANA RAMANUJAM ${ }^{2}$ \\ 'Department of Ecology and Environmental Science, Assam University, Silchar-788011, Assam, India. \\ ${ }^{2}$ Department of Zoology, North Eastern Hill University, Shillong 793022, Meghalaya, India.
}

http://dx.doi.org/10.12944/CWE.11.1.39

(Received: February 05, 2016; Accepted: February 29, 2016)

\begin{abstract}
Considering the significance of heavy metal pollution in aquatic system bioaccumulation of heavy metals in two species of tadpoles namely Clinotarsus alticola and Leptobrachium smithi collected from tea gardens of Barak valley, Assam was studied. Aquatic life is affected by heavy metal pollutants present in water as well as in sediment. The result of the study revealed that the concentration of iron, chromium, cadmium and lead in water samples was higher than the permissible limit of $0.3,0.05,0.003,0.01 \mathrm{mg} / \mathrm{L}$ respectively but that of copper and zinc concentration was within the maximum permissible limit of $2 \mathrm{mg} / \mathrm{L}$ and $3 \mathrm{mg} / \mathrm{L}$ (WHO, 2005). The accumulation pattern of different heavy metals in different organs viz., intestine, liver and tail was studied. Overall the metal burden in different organs of Clinotarsus alticola and Leptobrachium smithi was in the order of liver>tail>intestine. Liver had highest accumulation of metals while intestine accumulated the least. Iron ( $\mathrm{Fe})$ was highly and zinc $(\mathrm{Zn})$ was the least accumulated metal in both the tadpoles. The accumulation of heavy metals might be due to tea plantation influx water, domestic and associated anthropogenic activities.
\end{abstract}

Key words: anurans, bioaccumulation, heavy metals, tea estate.

\section{INTRODUCTION}

Anurans belonging to class amphibians occupy important position in the ecosystem being both predators and prey and are good bio-indicators of environmental pollution. Amphibians are intimately tied to aquatic as well as terrestrial environment and the quality of water in which they live can affect their growth, development, and survival. The negative impact of anthropogenic activities on biodiversity is becoming increasingly conspicuous and amphibians are currently the most globally threatened group of vertebrates, approximately $41 \%$ of all species ${ }^{1}$. Various causes for declining amphibian populations are habitat destruction, introduction of exotic species, pathogens, pollution, and global climate change. A variety of pollutants occur in natural habitats including fertilizers, pesticides and heavy metals introduced into the environment by direct application, runoff from crop, forest applications or mines, urban and industrial sewage, and atmospheric deposition ${ }^{2,3,4}$. Amphibians have permeable, exposed skin and eggs that may readily absorb toxic substances from the environment. Their biology and habitat selection makes them candidates for heavy metal accumulation ${ }^{5}$. Freshwater systems contaminates with heavy metals from industrial and agricultural sources ${ }^{6,7}$. The objective of the present study was to estimate the levels of heavy metals; copper $(\mathrm{Cu})$, iron $(\mathrm{Fe})$, chromium $(\mathrm{Cr})$, cadmium $(\mathrm{Cd})$, lead $(\mathrm{Pb})$ and zinc $(\mathrm{Zn})$ in tadpoles of two different anuran species - Clinotarsus alticola and 
Leptobrachium smithi belonging to two different families Ranidae and Megophryidae respectively and also the accumulation pattern in different organs viz., intestine, liver and tail. The study was conducted in aquatic systems of Rosekandy Tea Estate, Cachar, Assam.

\section{MATERIALS AND METHODS}

\section{Study site}

The study was conducted at Barjalenga $\left(24^{\circ} 422293-24^{\circ} 412313 \mathrm{~N}, 92^{\circ} 412523-92^{\circ} 422\right.$ 393 E), Rosekandy Tea Estate, Cachar District, Assam, $25 \mathrm{kms}$ from Silchar town. There are a number of permanent and temporary lentic and lotic water bodies (in the form of nullahs or drains) inside the tea gardens. The permanent standing water bodies are situated in disturbed as well as undisturbed areas and are adjacent to the forest and tea plantation area. The disturbed area contains human settlements, factories and tarred roads.

\section{Collection of samples}

Tadpoles of Leptobrachium smithi were collected from shallow water body and Clinotarsus alticola were collected from permanent lentic body with the help of dip net and were washed properly with double distilled water in the laboratory. The selected organs like intestine, tail and liver were removed and dried until reaching a constant weight. Digestion of samples was done according to ${ }^{8}$. To each sample of organs $(0.1 \mathrm{~g}), 10 \mathrm{ml}$ of perchloric acid: conc. $\mathrm{HNO}_{3}(3: 2 \mathrm{v} / \mathrm{v})$ was added and heated at $60^{\circ} \mathrm{C}$ until a clear solution was formed. The resulting solutions were cooled, and the volumes were made up to $50 \mathrm{ml}$ using double distilled water. The samples were then stored in plastic bottles till analysis to determine the amount of heavy metal bioaccumulated ${ }^{9}$. The water collected in sampling bottles were pre-conditioned with dilute nitric acid $\left(\mathrm{HNO}_{3}\right)$ and later rinsed thoroughly with double distilled water. Pre-cleaned polyethylene sampling bottles were immersed about $10 \mathrm{~cm}$ below the water surface and 1 liter of the water sample was taken. Samples were acidified with concentrated nitric acid $\left(\mathrm{HNO}_{3}\right)$ for preservation. The samples were filtered through Whatman filter paper No. 1 and kept in refrigerator until analysis. The sediment samples were oven dried at $45^{\circ} \mathrm{C}$ followed by grinding and sieving using $<2 \mathrm{~mm}$ sieve, $5 \mathrm{gm}$ of dry sample was poured into a beaker and mixed with $2 \mathrm{ml}$ of aqua regia 1:3 (1 conc. $\mathrm{HCL}: 3$ conc. $\mathrm{HNO}_{3}$ ). The mixture was digested on a hot plate in open beakers at $95^{\circ} \mathrm{C}$ for $1 \mathrm{hr}$ and allowed to cool to room temperature. The supernatant was filtered and then diluted to $50 \mathrm{ml}$ using distilled water. The heavy metal concentrations were determined with a Graphite Furnace- Atomic Absorption spectrophotometer (GF-AAS), Model Analytik Jena Vario-6.

\section{RESULTS AND DISCUSSION}

The heavy metals including copper $(\mathrm{Cu})$, iron $(\mathrm{Fe})$, chromium $(\mathrm{Cr})$, cadmium $(\mathrm{Cd})$, lead $(\mathrm{Pb})$ and zinc $(\mathrm{Zn})$ were analyzed in the intestine, liver and tail of two different tadpole species, Clinotarsus alticola and Leptobrachium smithi. Some physicochemical parameters of water were also determined as they are indicators of water quality. Table 1 presents the physico-chemical variables of the water in study sites.

The $\mathrm{pH}$ varied between 5.1-6.24 and conductivity ranged between $50.16 \mu \mathrm{sm}^{-1}$ to 50.26 $\mu \mathrm{cm} \mathrm{cm}^{1}$. Dissolved $\mathrm{O}_{2}$ ranged between $3.73 \mathrm{mg} \mathrm{L}^{-1}$ to $4.23 \mathrm{mg} \mathrm{L}^{-1}$ and Free $\mathrm{CO}_{2}$ ranged between 21.8 to $41.6 \mathrm{mg} \mathrm{L}^{1}$. Total Alkalinity ranged between 29.7 $\mathrm{mg} \mathrm{L}^{-1}$ to $44 \mathrm{mg} \mathrm{L}^{-1}$. Surface water temperature ranged from 22.63 to $24^{\circ} \mathrm{C}$. Air temperature ranged between $29.16^{\circ} \mathrm{C}$ to $29.26^{\circ} \mathrm{C}$. $\mathrm{pH}$ and alkalinity are important factors controlling metal fate, transport and bioavailability ${ }^{10}$. Metal uptake and their toxicity in aquatic fauna are influenced by many factors such as temperature, dissolved oxygen, hardness, alkalinity, $\mathrm{pH}$, salinity, suspended particulate matter, $\mathrm{pH}$, hardness, alkalinity and temperature of water ${ }^{11,12}$.

The levels of heavy metals: $\mathrm{Cu}, \mathrm{Fe}, \mathrm{Cr}, \mathrm{Cd}$, $\mathrm{Pb}$ and $\mathrm{Zn}$ in two different anuran species - Clinotarsus alticola and Leptobrachium smithi was analyzed (Table 2). The sequence of metal accumulation in the intestine (Fig.1a) and liver (Fig.1b) of Clinotarsus alticola was $\mathrm{Fe}>\mathrm{Pb}>\mathrm{Cr}>\mathrm{Cu}>\mathrm{Cd}>\mathrm{Zn}$, while in the intestine and liver of Leptobrachium smithi sequence of metal accumulation was, $\mathrm{Fe}>\mathrm{Cu}>\mathrm{Cr}>\mathrm{Pb}>\mathrm{Cd}>\mathrm{Zn}$ and $\mathrm{Fe}>\mathrm{Cu}>\mathrm{Cr}>\mathrm{Pb}>\mathrm{Zn}>\mathrm{Cd}$ respectively. The order of metal bioaccumulation in the tail of both Clinotarsus alticola and Leptobrachium smithi was $\mathrm{Fe}>\mathrm{Cr}>\mathrm{Pb}>\mathrm{Cu}>\mathrm{Cd}>\mathrm{Zn}$ (Fig. 2). Iron (Fe) was the highly and zinc $(\mathrm{Zn})$ was the least accumulated 
metal in both the tadpoles. Considering the metal burden in different organs of Clinotarsus alticola and Leptobrachium smithi it was in the order of liver>tail>intestine. Similar result was obtained in fish where maximum accumulation occurred in liver and least was in muscle ${ }^{13}$. In the present study also liver showed higher accumulation of metals than other organs.

The accumulation of $\mathrm{Fe}, \mathrm{Cr}, \mathrm{Cd}, \mathrm{Pb}$ and $\mathrm{Zn}$ in intestine of Clinotarsus alticola was higher in comparison to Leptobrachium smithi, while $\mathrm{Cu}$ accumulation in intestine of Leptobrachium smithi was higher than Clinotarsus alticola. The concentration of $\mathrm{Cu}, \mathrm{Fe}, \mathrm{Cr}$ and $\mathrm{Zn}$ was found to be highest in the liver of Leptobrachium smithi while concentration of $\mathrm{Cd}$ and $\mathrm{Pb}$ was recorded highest in Clinotarsus alticola. Heavy metal concentration was higher in the tail of Leptobrachium smithi as compared to Clinotarsus alticola

The sequence of metal accumulation in the sediment samples collected from the habitat of Clinotarsus alticola was $\mathrm{Pb}>\mathrm{Fe}>\mathrm{Cr}>\mathrm{Cu}>\mathrm{Cd}>\mathrm{Zn}$ and from the habitat of Leptobrachium smithi was
$\mathrm{Pb}>\mathrm{Fe}>\mathrm{Cu}>\mathrm{Cr}>\mathrm{Cd}>\mathrm{Zn}$. Lead $(\mathrm{Pb})$ concentration in sediment samples collected from the habitat of Leptobrachium smithi and Clinotarsus alticola was found to be highest and zinc ( $\mathrm{Zn})$ concentration was least (Fig. 3a).

The order of metal concentration in water samples collected from the habitat of Clinotarsus alticola was $\mathrm{Fe}>\mathrm{Cu}>\mathrm{Pb}>\mathrm{Cr}>\mathrm{Cd}>\mathrm{Zn}$ and from the habitat of Leptobrachium smithi was $\mathrm{Fe}>\mathrm{Pb}>\mathrm{Cu}>\mathrm{Cr}>\mathrm{Cd}>\mathrm{Zn}$. Iron (Fe) concentration was recorded highest and zinc $(\mathrm{Zn})$ concentration was least (Fig. 3b). The sediment and water samples collected from the habitat of Leptobrachium smithi accumulated high concentration of metals in comparison to that of Clinotarsus alticola.

The Bioaccumulation factor was calculated according to formula ${ }^{14}$

BAF=

Conc. of heavy metal in tissue

Conc. of heavy metal in abiotic media (water and sediment)

The results of Bioaccumulation factor (Table 3) showed that $\mathrm{Cr}, \mathrm{Pb}$ in C. alticola tadpoles from

Table 1: Physiochemical properties of water in two different study sites

\begin{tabular}{lccccccc}
\hline Species & $\begin{array}{c}\text { Air } \\
\text { Temp. } \\
\left({ }^{\circ} \mathbf{C}\right)\end{array}$ & $\begin{array}{c}\text { Surface } \\
\text { Water } \\
\text { Temp. }\left({ }^{\circ} \mathbf{C}\right)\end{array}$ & pH & $\begin{array}{c}\text { Cond. } \\
\left(\mu \mathbf{~ c m}^{-1}\right)\end{array}$ & $\begin{array}{c}\text { Dissolved } \\
\text { Oxygen } \\
\left(\mathbf{m g ~ L}^{-1}\right)\end{array}$ & $\begin{array}{c}\text { Free } \\
\mathbf{C O}_{2} \\
\left(\mathrm{mg} \mathrm{L}^{-1}\right)\end{array}$ & $\begin{array}{c}\text { Total } \\
\text { Alkalinity } \\
\left(\mathbf{m g ~ L}^{-1}\right)\end{array}$ \\
\hline 1. C. alticola & $29.26 \pm 0.2$ & $24 \pm 0.2$ & $6.24 \pm 0.08$ & $50.16 \pm 1.2$ & $3.73 \pm 0.15$ & $21.8 \pm 0.2$ & $44 \pm 1$ \\
2. L. smithi & $29.16 \pm 0.2$ & $22.63 \pm 0.4$ & $5.1 \pm 0.02$ & $50.26 \pm 0.7$ & $4.23 \pm 0.15$ & $41.6 \pm 0.4$ & $29.7 \pm 0.2$ \\
\hline
\end{tabular}

Table 2: Heavy metals concentrations in different organs of Clinotarsus alticola and Leptobrachium smithi $\left(\mu \mathrm{g} \mathrm{gm}^{-1}\right)$.

\begin{tabular}{|c|c|c|c|c|c|c|}
\hline \multirow[b]{2}{*}{$\begin{array}{l}\text { Metals } \\
\text { Organs }\end{array}$} & \multirow[b]{2}{*}{ Copper(Cu) } & \multicolumn{4}{|c|}{ Heavy metal concentration ( $\left.\mu \mathrm{g} \mathrm{gm}^{-1}\right)$} & \multirow[b]{2}{*}{ Zinc(Zn) } \\
\hline & & \multicolumn{4}{|c|}{ Clinotarsus alticola } & \\
\hline Intestine & $0.122 \pm 0.077$ & $1.233 \pm 0.647$ & $0.166 \pm 0.035$ & $0.021 \pm 0.016$ & $0.169 \pm 0.092$ & $0.009 \pm 0.006$ \\
\hline Liver & $0.48 \pm 0.311$ & $5.57 \pm 0.608$ & $1.365 \pm 0.968$ & $0.195 \pm 0.077$ & $1.625 \pm 2.015$ & $0.06 \pm 0.056$ \\
\hline Tail & $0.09 \pm 0.070$ & $0.58 \pm 0.240$ & $0.154 \pm 0.072$ & $0.029 \pm 0.015$ & $0.138 \pm 0.002$ & $0.022 \pm 0.015$ \\
\hline \multicolumn{7}{|c|}{ Leptobrachium smithi } \\
\hline Intestine & $0.126 \pm 0.082$ & $0.560 \pm 0.319$ & $0.096 \pm 0.016$ & $0.019 \pm 0.003$ & $0.066 \pm 0.024$ & $0.008 \pm 0.002$ \\
\hline Liver & $2.25 \pm 1.626$ & $8.825 \pm 2.298$ & $2.125 \pm 0.106$ & $0.145 \pm 0.007$ & $0.775 \pm 0.388$ & $0.25 \pm 0.212$ \\
\hline Tail & $0.113 \pm 0.074$ & $0.902 \pm 0.130$ & $0.217 \pm 0.038$ & $0.066 \pm 0.062$ & $0.145 \pm 0.119$ & $0.025 \pm 0.020$ \\
\hline
\end{tabular}


water were greater than that from sediment and this implies that the tadpoles bioaccumulated these metals from the water ${ }^{14}$. Also the accumulation of $\mathrm{Cu}$, $\mathrm{Cd}$ and $\mathrm{Zn}$ in tadpoles of $C$. alticola from water were lower than that from sediment and this implies that the tadpoles bioaccumulate these heavy metals from the sediment. Similar report has been made where significant correlation was found between heavy metal accumulation in tadpoles and the respective levels in the sediments and water ${ }^{15}$. Tadpoles are omnivorous, macrophagous filter feeder and ingest anything from sediment. Hence they may accumulate elements from sediment. Bioaccumulation factor (Table 4) of $\mathrm{Cu}, \mathrm{Cr}, \mathrm{Pb}$ in L. smithi tadpoles from water were greater than that from sediment and this implies that the tadpoles bioaccumulated these metals from the water. Also the accumulation of $\mathrm{Fe}, \mathrm{Cd}, \mathrm{Zn}$ in tadpoles of L. smithi from water were lower than that from sediment and this implies that the tadpoles bioaccumulated these heavy metals from the sediment. This might be due to the feeding behavior of tadpoles which feeds at the bottom of the habitat or sequester metal from the habitats.

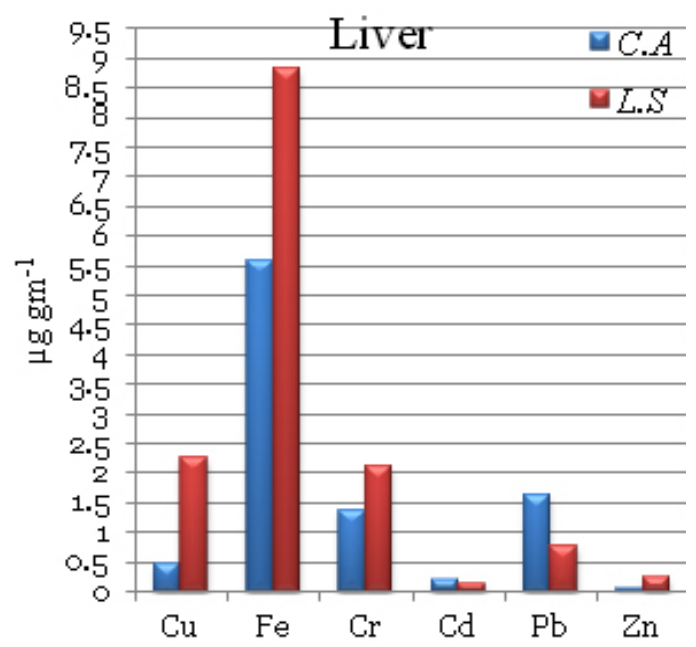

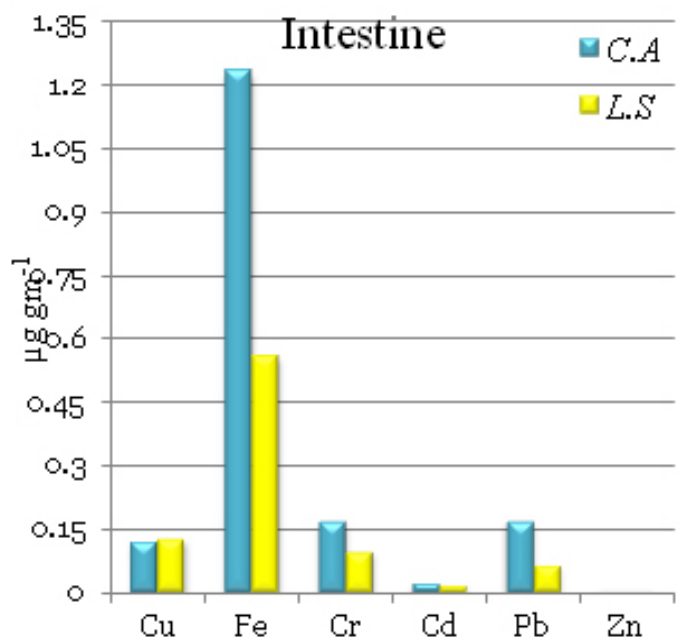

Fig.1 (a and b): Heavy metal bioaccumulation in intestine and liver of C. alticola and L. smithi

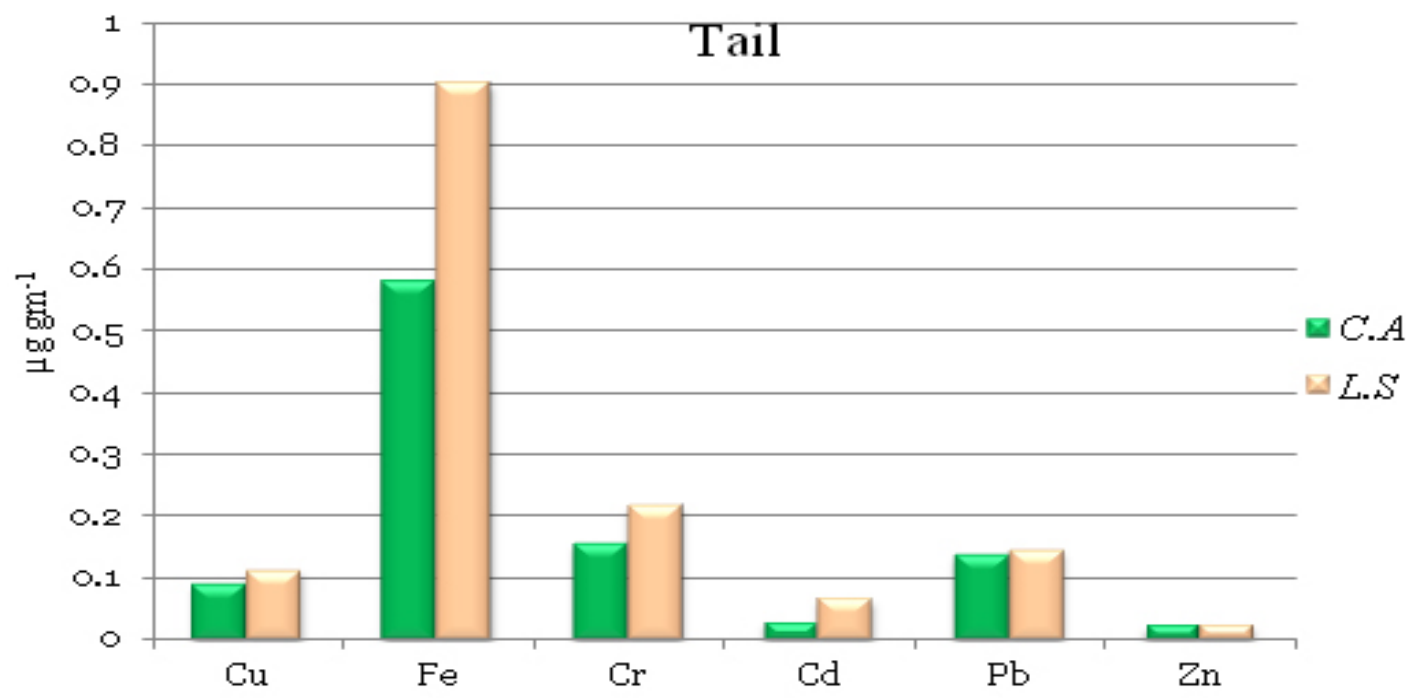

Fig. 2: Heavy metal bioaccumulation in tail of Clinotarsus alticola and Leptobrachium smithi 
The present study reveals that liver of both the tadpoles accumulated more concentration of metals when compared to other organs. The liver plays an important role in accumulation and detoxification of heavy metals ${ }^{16}$. The differences in accumulation of metal in the liver, tail and intestine of the two tadpole species could be attributed to differences in their physiological roles. It has been reported that different organisms have different metabolic rates and different food requirements and amounts. Organisms with high food intake tend to accumulate more metals ${ }^{17}$. Concentration of iron (Fe) was highest in different organs of tadpole and in the water samples but metal concentrations in the different organs of tadpoles showed differences in accordance to the concentration of metals in sediment. Lead $(\mathrm{Pb})$ was the highest accumulated metal in both the sediment samples. Zinc (Zn) was the least accumulated metal in the tadpole, sediment and water samples. The result revealed that the concentration of iron, chromium, cadmium and lead in water samples was higher than the permissible limit of $0.3,0.05,0.003,0.01 \mathrm{mg} / \mathrm{L}$ respectively but copper and zinc concentration was within the maximum permissible limit of $2 \mathrm{mg} / \mathrm{L}$ and $3 \mathrm{mg} / \mathrm{L}$ (WHO, 2005). Heavy metals contamination may have a significant impact on aquatic organisms, disturbing the ecological balance and potentially contaminating the aquatic food chain as well as humans ${ }^{18}$. Accumulation of such metals by animal tissue may be transferred to next higher level of

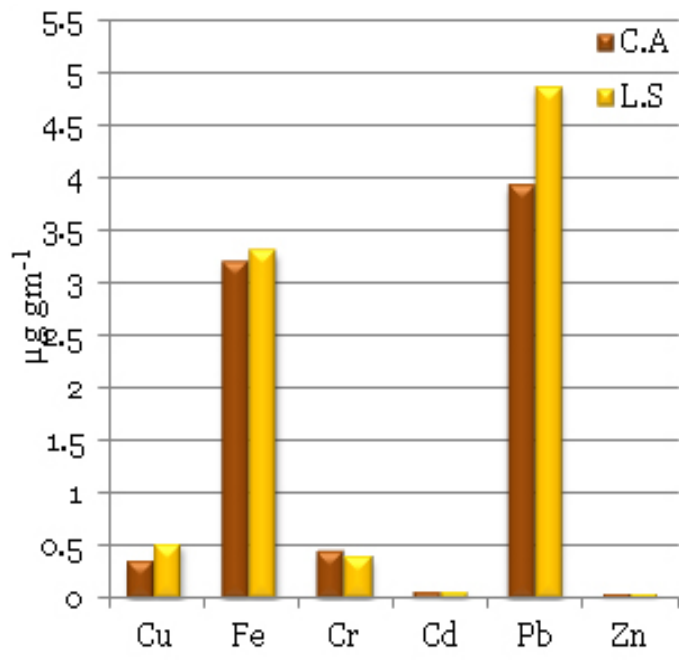

organism through food chain. Such studies have been conducted in fish which is consumed as an important protein diet $^{19}$.

There are many factors, physicochemical and biological factors, affecting the accumulation and toxicity of metals in aquatic organisms. Cd and $\mathrm{Pb}$ entering aquatic systems from industrial and consumer waste and can damage physiological processes or accumulate in tissues of aquatic organisms even at concentrations far below the lethal level ${ }^{20}$. Cd and $\mathrm{Pb}$ increased the mortality and malformation ratio and prolonged the development and metamorphosis period in tadpoles ${ }^{21}$. Sediments accumulated more heavy metals than water ${ }^{22}$ and same was also observed in the present study. Given the static nature of sediments, they tend to accumulate more toxicant than water which may flow away, drain off or even evaporate ${ }^{23}$. In the present study area influx of water from tea plantation and other anthropogenic activities may account for higher concentration of heavy metals in sediment which may lead to serious environmental problems and finally affect the anuran tadpole population and their life cycle. Heavy metal concentration in sediment as well as in water was found to affect occurrence of anuran and species richness in any system ${ }^{24}$. From the present study it can be concluded that the tadpoles can be considered as a good bio-indicators of metals contamination in streams and other aquatic bodies. In different sampling sites there was

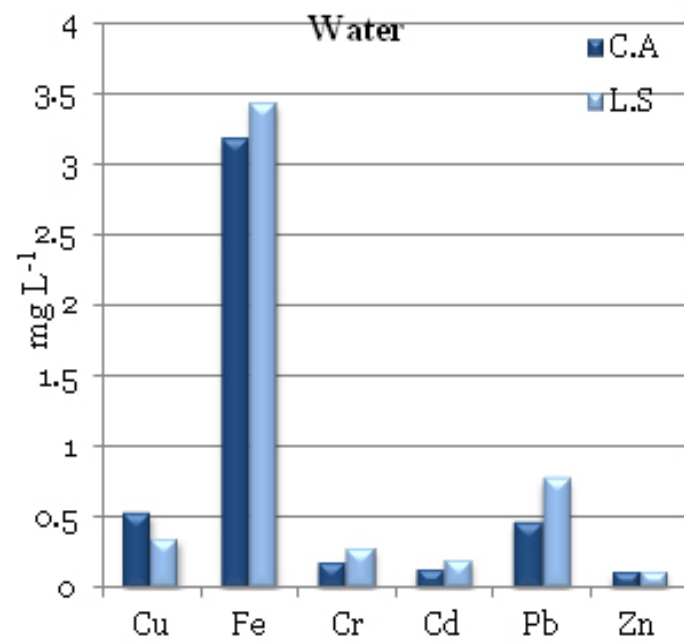

Fig. 3 ( $a$ and b): Heavy metal concentrations in sediment and water of Clinotarsus alticola and Leptobrachium smithi habitats 
Table 3: Bioaccumulation factors of heavy metals in different organs of Clinotarsus alticola

\begin{tabular}{lcccccc}
\hline C. alticola & $\mathbf{C u}$ & $\mathbf{F e}$ & $\mathbf{C r}$ & $\mathbf{C d}$ & $\mathbf{P b}$ & $\mathbf{Z n}$ \\
\hline Liver/water & 0.91 & 1.75 & 7.89 & 1.44 & 3.53 & 0.56 \\
Liver/sediment & 1.40 & 1.74 & 3.13 & 4.14 & 0.14 & 1.62 \\
Tail/water & 0.17 & 0.18 & 0.89 & 0.21 & 0.3 & 0.20 \\
Tail/sediment & 0.26 & 0.19 & 0.34 & 0.61 & 0.03 & 0.59 \\
Intestine/water & 0.23 & 0.38 & 0.95 & 0.15 & 0.36 & 0.08 \\
Intestine/sediment & 0.35 & 0.40 & 0.36 & 0.44 & 0.04 & 0.24 \\
\hline
\end{tabular}

Table 4: Bioaccumulation factors of heavy metals in different organs of Leptobrachium smithi

\begin{tabular}{lcccccc}
\hline L. smithi & Cu & Fe & Cr & Cd & Pb & Zn \\
\hline Liver/water & 6.42 & 2.57 & 7.72 & 0.73 & 1.01 & 2.13 \\
Liver/sediment & 4.32 & 2.68 & 5.42 & 2.23 & 0.15 & 6.75 \\
Tail/water & 0.32 & 0.26 & 0.78 & 0.33 & 0.18 & 0.21 \\
Tail/sediment & 0.21 & 0.27 & 0.55 & 1.01 & 0.02 & 0.67 \\
Intestine/water & 0.36 & 0.16 & 0.34 & 0.09 & 0.08 & 0.06 \\
Intestine/sediment & 0.24 & 0.17 & 0.24 & 0.29 & 0.01 & 0.21 \\
\hline
\end{tabular}

contamination by pollutants and long time exposure of anuran tadpoles to heavy metals may lead to decline of the anuran population in the region.

In view of the importance of anurans in ecosystems, it is recommended that monitoring of water and sediment in various habitats should be done regularly. Proper disposal techniques of industrial effluents, agricultural drainage water containing pesticides, fertilizers and domestic sewage should be practiced to avoid entry of these metals into environment which may lead to severe pollution of water bodies.

\section{ACKNOWLEDGMENTS}

The authors are grateful to SAIF, NEHU, Shillong for the use of AAS. First and second authors express their gratitude to UGC, New Delhi for providing financial support. The authors are also grateful to the Department of Ecology and Environmental Science, Assam University, Silchar where the work was carried out.

\section{REFERENCES}

1. Hoffmann, M., Hilton-Taylor, C., Angulo, A., Böhm, M., Brooks, T.M., Butchart, S.H.M., Carpenter, K.E., Chanson J, Collen B, Cox $N A$, et al. The impact of conservation on the status of the world's vertebrates. Science, 330:1503-1509 (2010)

2. Vitousek PM, Aber J, Howarth RW, Likens GE, Matson PA, Schindlerm DW, Schlesinger WH,
Tilman GD. Human alteration of the global nitrogen cycle: causes and consequences. Ecological Applications, 7: 737-750 (1997)

3. Linder G, Grillitsch B. Ecotoxicology of metals. In: Sparling DW, Linder G, Bishop CA, editors. Ecotoxicology of amphibians and reptiles. Pensacola, FL: Society of Environmental Toxicology and Chemistry (SETAC), pp. 325- 
459 (2000)

4. Sparling, D.W., Linder, G.L. and Bishop, C.A. Eco-toxicology of Amphibians and Reptiles. Society of Environmental Toxicology and Chemistry, 2nd Edition, Par-sacola, Fla, p. 877 (2000) 5. Hayes, T.B., Falso, P., Gallipeau, S. and Stice, M. The cause of global amphibian declines: a developmental endocrinologist's perspective. Journal of Experimental Biology, 213: $921-933$ (2010)

6. Greig, H.S., Niyogi, D.K., Hogsden, K.L., Jellyman, P.G. and Harding, J.S. Heavy metals: confounding factors in the response of New Zealand freshwater fish assemblages to natural and anthropogenic acidity. Science of the Total Environment, 408: 3240-50 (2010)

7. HopkinsW. and Rowe C. (2010) Interdisciplinary and hierarchical approaches for studying the effects of metals and metalloids on amphibians. In: Ecotoxicology of Amphibians and Reptiles, Second Edition. CRC Press.

8. FAO/SIDA. Manual of methods in aquatic environmental research part 9. Analysis of metals and organochlorines in fish. FAO fisheries/Technical paper 212 (1983).

9. Ezemonye, L.I. and Enuneku, A.A. Hepatic bioaccumulation of cadmium in the crowned bullfrog, Hoplobatrachus occipitalis and flat backed toad, Bufo maculates. International Journal of Aquatic Science, 3(1):15-22 (2012)

10. Adhikari, S., Ghosh, L. and Ayyappan, S. Combined effects of water $\mathrm{pH}$ and alkalinity on the accumulation of lead, cadmium and chromium to Labeo rohita (Hamilton). International Journal of Environmental Science and Technology, 3(3):289-296 (2006)

11. Karakoç, M. Effects of Salinity on the Accumulation of Copper in Liver, Gill and Muscle Tissues of Tilapia nilotica. Turkish Journal of Zoology, 23:299-303 (1999)

12. Osman, A.G. and Kloas, W. Water Quality and Heavy Metal Monitoring in Water, Sediments, and Tissues of the African Catfish Clarias gariepinus (Burchell, 1822) from the River Nile, Egypt. Journal of Environmental Protection, 1:389-400 (2010)

13. Ambedkar, G. and Muniyan, M. Analysis of heavy metals in water, sediments and selected freshwater fish collected from Gadilam River, Tamilnadu, India. International Journal of Toxicology and Applied Pharmacology, 2(2):25-30 (2012)

14. Barron MG. Bioaccumulation and concentration in aquatic organisms. In: Hoffman, D.J., Rattner, B.A., Burton, Jr., G.A., Cairns, J. (Eds.), Handbook of Ecotoxicology. Lewis Publishers, Boca Raton, FL.; 652-666 (1995)

15. Kelepertzis, E., Argyraki, A. and Daftsis, E. Geochemical signature of surface water and stream sediments of a mineralized drainage basin at NE Chalkidiki, Greece: a pre-mining survey. Journal of Geochemical Exploration, 114:70-81 (2012)

16. Yousafzai, A.M. Toxicological Effects of Industrial Effluents Dumped in River Kabul on Mahaseer, Tor Putitora at Aman Garh Industrial Area Nowshera, Peshawar, Pakistan, Ph.D. Thesis, University of the Punjab, Lahore, (2004)

17. Ademoroti, C.M.A. Environmental Chemistry and Toxicology mFoludex. Press, Ibadan. 215 (1996)

18. Saeed, S.M. and Mohammed M.A. Influence of Physico-Chemical Characteristics of Water on Metals Accumulation in Water and Tilapia Zillii Inhabiting Different Habitats in Egypt. Journal of the Arabian Aquaculture society, 7(1):29-48 (2012)

19. Asante, F., Agbeko, E., Addae, G. and Quainoo, A.K. Bioaccumulation of Heavy Metals in Water, Sediments and Tissues of Some Selected Fishes from the Red Volta, Nangodi in the Upper East Region of Ghana. British Journal of Applied Science \& Technology, 4(4):594-603 (2014)

20. He, Z.L., Yang, X.E., Stoffella, P.J. Trace Eelements in Agroecosystems and Impacts on the Environment. Journal of Trace Elements in Medicine and Biology, 19(2-3):125-40 (2005)

21. Huang, D.J., Zhang, Y.M., Zhao, D.Q., Long, J., Wang, G.Y., Hu, Z.D. Effect of cadmium on the development of tadpoles of the Bufo raddei. Journal-Lanzhou University Natural Sciences, 40(2):81-83 (2004)

22. Don-Pedro, K.N., Oyewo, E.O., Otitoloju, A.A. Trend of heavy metal concentrations 
in Lagos lagoon ecosystem, Nigeria. West Afirican Journal of Applied Ecology, 5:103114 (2004)

23. Taiwo, I.E., Henry, A.N., Imbufe, A.P. and Adetoro, O.O. Heavy metal bioaccumulation and biomarkers of oxidative stress in the wild African tiger frog, Hoplobatrachus occipitalis. African Journal of Environmental Science and
Technology, 8(1):6-15 (2014)

24. Ficken, K.L.G. and Byrne, P.G. Heavy metal pollution negatively correlates with anuran species richness and distribution in southeastern Australia. Austral Ecology: a journal of ecology in the Southern Hemisphere, 38(5):523-533 (2013). 